\title{
PECULIARITIES OF A FOREIGN LANGUAGE TEACHER'S WORK IN THE CONDITIONS OF DISTANCE EDUCATION
}

The article defines the current state of distance learning integration into the educational mechanism of higher educational establishments in Ukraine during the Covid-19 pandemic. The analysis of the recent research substantiates its expediency despite certain negative aspects and limitations that came to surface (especially on the initial stage of transition to it), which should be eliminated for this system to bring more positive outcomes. While implementing distance learning technologies, many important issues like content, motivation, mental/physical health, technical assistance and ability to provide feedback must be taken into consideration.

The article deals with some peculiarities of teachers' work in training foreign languages for specific purposes in the conditions of distance education. It reflects a new understanding of an educator's role in providing efficient organization of the educational process, stressing the necessity of developing such core competencies, as self-discipline, time management, communication and information technology skills. Among the IT skills, possessing basic computer knowledge and operational skills, planning and management, computer mediated communication, assessment and evaluation skills is considered to be beneficial for a foreign language teacher.

In the article, some peculiarities and difficulties of the practical work of teachers and students in an electronic educational environment, while working with various online platforms, synchronous, asynchronous or hybrid modes, are highlighted. To enhance students' motivation and engagement with the learning process, the emphasis is made on diversifying learning activities, using, for example, TED Ed videos or Learning Apps interactive tasks, consistent with the curricula. Updating learning materials and developing online language courses are necessary to meet the requirements of distance learning.

To eliminate stresses and feel more comfortable with technology and remote classes, teachers are recommended to attend webinars, online conferences, to get acquainted with new strategies for teaching remotely. Self-education, which foresees self-improvement and professional growth, is an obligatory option.

Key words: distance learning, synchronous/asynchronous modes, online platform, competencies, IT skills, interactive assignments, teaching strategies.

Introduction. The Covid-19 pandemic has inevitably influenced the quality of higher education, triggered news ways of learning and checked the society's ability and readiness to adapt to constantly changing circumstances and conditions. In the light of recent events, a shift to distance and blended education became a salvation for many higher educational institutions worldwide. In spite of some negative aspects and limitations that came to surface, especially on the initial stage of its implementation, including the lack of technical resources and experience, distance learning proved its expediency. Much research has been done on the necessity and possibility of integrating the best elements of traditional and distance learning into a so-called "blended learning" to provide more comfortable learning conditions for students.

Previous research analysis. The problem of distance learning and implementing distance learning strategies provokes significant scientific interest, especially nowadays, as something which is challenging and ambiguous, though not new. V. Yasulaitis, V. Bykov, T. Koval, I. Zaytseva, A. Zasluzhena, I. Prokopenko, S. Berezhna, etc. analyzed basic prin- ciples and specific features of distance learning and innovative technologies used in it.

The concept "distance learning" is defined as a process of acquiring knowledge and skills in which there is an indirect interaction between a learner and a teacher, separated in space or in time, carried out in a specialized environment which functions on the basis of modern pedagogical, information and communication technologies [1]. This implies a learner's independence and autonomy with the least face-toface interaction with the instructor, responsibility for his own learning progress and achievements, a great amount of learning materials and assignments, open access to all educational resources and programs. $\mathrm{V}$. Yasulaitis states that this type of learning has the same objectives, principles and content as the traditional one, thus can be well integrated into it [2].

While implementing distance learning technologies, many important issues like content, motivation, mental health, technical assistance and feedback must be taken into consideration. If they are thoroughly provided, the participants can fully enjoy the advantages of distance learning, among the most important of which are: 
- a wide range of audio, video, text, graphic learning materials at their disposal;

- free access to a great variety of electronic resources;

- structurization and multi-access to the given information;

- flexibility of the schedule as the time mode and place are regulated by learners;

- individual approach to every learner;

- ability to avoid psychological or communication barriers connected with learners' fears, shyness, stresses, etc.;

- getting a feedback from a teacher;

- ability to self-educate and develop new skills;

- ability to combine learning with professional activity, etc.

However, distance learning opponents emphasize the following negative aspects as:

- lack of proper emotional contact, non-verbal communication, direct student-teacher, student-student interaction;

- technical obstacles, like problems with gadgets, low-speed network bandwidth, lack of data security;

- insufficient experience in working with online-platforms;

- problems with identification and authentication;

- long hours in front of PCs, which can have a negative impact on health;

- self-discipline, planning and time management must be always kept at a high level etc.

Trying to explain the difficulties with distance education, S. Vykhor and O. Radchenko state that they are caused by psychological problems that learners encounter while studying remotely as a result of global changes which, in their turn, lead to the changes in the system of values and demand a quick adaptation and psychological restructuring under new circumstances, which can't be easily achieved by all learners equally [3].

A great number of visual multimedia products and electronic methodological resources have been developed and are currently under development to make distance learning more efficient, meaningful, so that it wouldn't concede to the traditional type of training and could facilitate students' knowledge acquisition. The role and competencies of teachers, language teachers in particular, have also undergone certain changes.

Thus, the aim of our research is to study peculiarities of teachers' work in training foreign languages for specific purposes, especially concerning the development of their new competencies and their interaction with students in the conditions of distance education during the Covid-19 pandemic.

Research results. In our digital age, being a fluent and creative user of technology, capable of integrating it into training, is particularly important, even for a foreign language teacher. Out of 98 information tech- nology competencies, identified by the Delphi panel of experts, Norizan Abdul Razak and Mohamed Amin Embi have tried to select and categorize into levels the ones which are necessary for language teachers, explaining this by the fact that they have to deal with more activities related to language competency and less to technical competency [4]:

1. Basic Computer Knowledge and Operational Skills, including:

- the ability to run the operating systems;

- install computer programs or applications;

- use spreadsheets or presentation programs;

- basic knowledge of computer concepts, terminology, characteristics.

2. Teaching and Learning Skills:

- ability to integrate applications software in teaching/learning process;

- ability to use Internet facilities, browsers, navigation tools, search engines to conduct information search, communicate or download the materials;

- ability to utilize and develop web-based materials;

- ability to give online consultations.

3. Planning and Managing Computer Based Environment:

- ability to support an effective computer-based environment;

- ability to plan, structure and integrate computer-assisted instruction into language curricula.

4. Assessment and Evaluation:

- ability to analyze the reliability of online materials;

- ability to handle computerized testing;

- ability to evaluate students' achievements and efficiency of computer use in the educational process, etc.

During the quarantine restrictions, when lectures are given remotely with the involvement of a great number of digital devices and e-resources, possessing these competencies can be beneficial for a foreign language teacher. The results of the conducted research demonstrated that $73 \%$ of foreign language teachers at Petro Mohyla Black Sea National University who had previous experience of using technology in their practice reported an easier and less stressful transformation to distance learning, though they had never tried remote or blended teaching before.

Undoubtedly, distance education sets new requirements and demands acquiring new competencies by foreign language teachers, for example, concerning efficient organization of the educational process through the simultaneous use of various platforms and modes. Moodle, which offers numerous opportunities for learning, serves as the basic one in many universities. Compared to the recent years, when it was primarily used for giving assignments, its role has modified and expanded, making it an independent constituent in the general system of education [3]. 
The specifics of foreign language teaching allow students and teachers to have live-chat discussions and interaction synchronously (or in a hybrid way) more often than the other university disciplines can afford. The synchronous mode implies a completion of tasks and activities by all students at the same time or live. In asynchronous learning, on the contrary, instructors set up a learning path, which students engage with at their own pace, not limited by time or place [5].

Indeed, the majority of distance foreign language classes are organized with the help of Zoom, Google Meet, Skype video-conferences which enable the teacher to virtually interact with the group when classroom in-person meetings are impossible. The core features which make them useful for foreign language classes include:

- ability to host a group of students synchronously;

- screen sharing, sharing and playing videos, PowerPoint presentations;

- instant chatting;

- video recording;

- quick access to the app when downloaded on a PC or a smartphone, etc.

Obviously, each of the platforms has their own peculiarities which teachers should get acquainted with to be able to select the most relevant one.

About $76 \%$ of English teachers at Black Sea National University first started using Zoom conferencing during the quarantine and, in spite of a 40-minute time limit for a Zoom session, consider it quite suitable for accomplishing academic goals. Nearly $15 \%$ of teachers who have previous experience of using Skype continue giving preference to it, while Google Meet is the least popular. Other Google services, like Google documents, Google tables and Google presentations, are also found helpful in teaching.

To make the whole mechanism work properly, teachers are to understand how to coordinate, motivate and direct the cognitive activity of the students. To achieve this, they have to develop or improve their language courses, update their learning materials and transform them into electronic resources accessible to their students at any time and from any place. Content of the educational courses is prioritized and put in the foreground [6].

Preparation for teaching online, as a rule, is effortand time-consuming, as it involves planning, forecasting, developing necessary didactic e-materials and selecting appropriate methods to use, results evaluation and giving feedback. Effective time management (correct timing) and self-discipline are essential competencies for a teacher working remotely to train.

Paradoxically, though students feel more comfortable with their apps and digital devices, they easily get lost in the maze of assignments. So clear instruc- tions and prompts, links to the materials, criteria for assessing are to be provided by teachers in advance. As a rule, special attention should be given to the firstyear students who have low or insufficient readiness for independent or autonomous work, so they need to be constantly motivated and given a detailed explanation of the possible difficulties they may encounter while learning this or that grammar or lexical material.

One of the helpful online tools for educators is TED Ed. It's a "lesson creator platform" that allows them to structure assignments around a video and assess students' engagement with the material [7]. High-quality videos classified by subject matter, for example, entertainment and design, science and technology, literature and language, sustainable development and medicine, are accompanied with a series of multiple-choice or open-ended questions ("Think"), interactive class discussion ("Discuss"), additional resources to encourage further independent exploration ("Dig deeper"). The advantage is that teachers (or students) can either use the existing extensive library of lesson plans, co-created by educators around the world, and choose the ones which are consistent with the curricula. Or they can create a lesson of their own, sharing the link with students or other educators. Moreover, the tasks can be easily adapted for pre-assessment, as well as formative or summative assessment purposes, done online.

TED Talks, in the form of short lectures, touch upon the urgent problems of education, technology, global environmental or personal issues, for example: What inspires you? Can machines read your emotions? What makes Earth so special? Do schools kill creativity? The videos from expert speakers last approximately 18 minutes, which is enough to draw and hold the audience's attention and interest to the presented topic. They are ideal for flipped-class lessons or asynchronous distance learning.

For a teacher, assessing students' progress in language acquisition and promoting their self-study have become possible with another multimedia product, such as LearningApps.org. It allows creating interactive tasks with the help of various templates, in such a way forming a set of didactic materials which can be shared via any existing platforms. Moreover, students can also be engaged in working out interactive products of their own.

Incorporating such efficient teaching strategies into the online classroom activity as Jigsaw method, Think-Pair-Share, Two Stars and a Wish, an Exit Ticket and others help teachers ensure students' active participation in discussions, their deeper understanding of the material, development of their active thinking and collaboration skills, even in the distance learning mode.

Conclusions. The transition to distance learning imposed by the Covid-19 pandemic brought out new understanding of the educator's role in provid- 
ing efficient organization of the educational process. It demands developing competencies, including time management, self-discipline, communication and IT skills while working simultaneously with various online platforms, in different modes, with numerous e-resources, to provide a better interaction with students. The emphasis is put on the necessity of diversifying learning activities to enhance students' motivation, on updating learning materials and developing the new ones, on improving the existing language courses to make them meet the requirements of distance learning.

It's worth noting that for teachers, to feel more comfortable with technology and remote classes, self-education, which foresees self-improvement and professional growth, is an obligatory option. A great number of webinars, online conferences, YouTube videos are at their disposal, which can promote their new skills acquisition and facilitate their adaptation to the changes evoked by the implementation of distance learning.

\section{References:}

1. Положення про дистанційне навчання : документ z 0703-13, редакція від 16 жовтня 2020 р., підстава z 0941-20. URL: https://zakon.rada. gov.ua.
2. Ясулайтіс В. Дистанційне навчання : методичні рекомендації. Київ, 2005. 54 с.

3. Вихор С., Радченко О. Особливості практичного впровадження дистанційного навчання під час викладання предметів педагогічного циклу у ЗВО. Актуальні питання гуманітарних наук : міжвузівський збірник наукових праць молодих вчених Дрогобицького державного педагогічного університету імені Івана Франка. Дрогобич : Видавничий дім «Гельветика», 2021. Вип. 35. Т. 1. С. 297-305.

4. Norizan Abdul Razak, Mohamed Amin Embi. A Framework of IT Competency for English Language Teachers. Internet Journal of E-Language Learning and Teaching. January 2004. № 1 (1). P. 1-14.

5. Asynchronous vs. Synchronous Learning : A Quick Overview. URL: https://www.brynmawr.edu.

6. Зайцева І., Заслужена А. Специфіка дистанційного навчання за умов пандемії коронавірусу. Актуальні питання гуманітарних наук : міжвузівський збірник наукових праць молодих вчених Дрогобицького державного педагогічного університету імені Івана Франка. Дрогобич : Видавничий дім «Гельветика», 2021. Вип. 34. T. 2. C. $265-271$.

7. TED Ed-Online Tools for Teaching and Learning. URL: https://blogs.umass.edu.

\section{Чуєнко В. Специфіка роботи викладача іноземної мови в умовах дистанційної освіти}

Стаття визначає сучасний стан інтегрування дистанційної освіти в освітній механізм вищих закладів освіти в Україні під час пандемії. Аналіз останніх наукових досліджень у цій галузі довів доцільність застосування дистанційних технологій, незважаючи на деякі негативні аспекти й обмеження, які вийшли на поверхню, особливо на початковому етапі переходу, та які мають бути усунені для того, щоб ия система приносила більшу результативність. У разі застосування дистанційних технологій такі важливі аспекти, як зміст, мотивація, фрізичне та розумове здоров'я, технічне обладнання та зворотний зв'язок, мають бути взяті до уваги.

Стаття розкриває специфріку роботи викладачів іноземної мови за профресійним спрямуванням в умовах дистанційної освіти. Вона відображає нове уявлення про роль викладача в забезпеченні ефрективності організації освітнього процесу, наголошує на необхідності розвитку таких його ключових компетенцій, як: самодисципліна, уміння правильно розподіляти час, комунікативні й інфрормаційно-технічні навички.

У статті висвітлюються деякі особливості та труднощі проведення практичної роботи викладачами та студентами в електронному освітньому просторі, коли $\epsilon$ необхідність застосування водночас декількох онлайн-платформ, синхронного, асинхронного та гібридного режимів тощо. Наголошується важливість урізноманітнення видів класної та домашньої роботи для посилення мотивації студентів до навчання й активного їх залучення до пізнавальної діяльності. Корисними можуть бути цікаві відео платфоорми TED Ed, інтерактивні завдання 3 Learning Apps, особливо якщо вони відповідають змісту навчальних програм. Оновлення та розроблення електронних навчальних матеріалів, онлайн-курсів з мови сприятимуть полегшенню впровадження ідей дистанційного навчання.

Для уникнення стресових ситуацій і покращення інформаційно-технічних навичок викладачам рекомендовано відвідування вебінарів, онлайн-конференцій, які дозволять їм ознайомитися 3 новітніми технологіями та методами викладання в дистанційному режимі. Підкреслено важливу роль самоосвіти.

Ключові слова: дистанційне навчання, синхронний/асинхронний режим, онлайн-платформа, компетенції, інформаційно-технічні навички, інтерактивні завдання, методи викладання. 